\title{
Technical Note: Ensuring consistent, global measurements of very short-lived halocarbon gases in the ocean and atmosphere
}

\author{
J. H. Butler ${ }^{1}$, T. G. Bell ${ }^{2}$, B. D. Hall ${ }^{1}$, B. Quack $^{3}$, L. J. Carpenter ${ }^{4}$, and J. Williams ${ }^{5}$ \\ ${ }^{1}$ Global Monitoring Division, NOAA Earth System Research Laboratory, Boulder, Colorado, USA \\ ${ }^{2}$ Laboratory for Global Marine and Atmospheric Chemistry (LGMAC), School of Environmental Sciences, University of East \\ Anglia, Norwich, NR4 7TJ, UK \\ ${ }^{3}$ Marine Biogeochemie-Chemische Ozeanographie, Leibniz-Institut für Meereswissenschaften (IFM-GEOMAR), \\ Kiel, Germany \\ ${ }^{4}$ Department of Chemistry, University of York, Heslington, York YO10 5DD, UK \\ ${ }^{5}$ Max Planck Institute for Chemistry, Mainz, Germany
}

Received: 6 April 2009 - Published in Atmos. Chem. Phys. Discuss.: 5 May 2009

Revised: 2 October 2009 - Accepted: 5 January 2010 - Published: 18 January 2010

\begin{abstract}
Very short-lived halocarbons are significant sources of reactive halogen in the marine boundary layer, and likely in the upper troposphere and lower stratosphere. Quantifying ambient concentrations in the surface ocean and atmosphere is essential for understanding the atmospheric impact of these trace gas fluxes. Despite the body of literature increasing substantially over recent years, calibration issues complicate the comparison of results and limit the utility of building larger-scale databases that would enable further development of the science (e.g. sea-air flux quantification, model validation, etc.). With this in mind, thirtyone scientists from both atmospheric and oceanic halocarbon communities in eight nations gathered in London in February 2008 to discuss the scientific issues and plan an international effort toward developing common calibration scales (http://tinyurl.com/c9cg58). Here, we discuss the outputs from this meeting, suggest the compounds that should be targeted initially, identify opportunities for beginning calibration and comparison efforts, and make recommendations for ways to improve the comparability of previous and future measurements.
\end{abstract}

\section{Introduction}

For this discussion, we consider very short-lived halocarbons as those that have atmospheric lifetimes of less than six months in the atmosphere. This definition is consistent

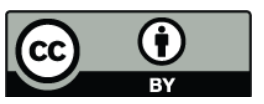

Correspondence to: T. G. Bell

(thomas.bell@uea.ac.uk) with that given in the 2002 and 2006 Scientific Assessments of Ozone Depletion (Ko and Poulet, 2003; Law and Sturges, 2007); it differs from the definition of "short-lived gases" in the 1998 Ozone Assessment (Kurylo and Rogriguez, 1999), which used one year as an upper limit and included methyl bromide. We understand that there are other definitions of "short-lived" and "very short lived" gases with much shorter lifetimes (e.g. Olsen et al., 2000), but using definitions having upper limits of a few months or less, while covering many gases of interest, would exclude several gases likely involved in stratospheric ozone depletion, e.g., $\mathrm{CH}_{2} \mathrm{Br}_{2}$, and which are not necessarily well distributed in the atmosphere.

Very short-lived halocarbons have been implicated as significant sources of reactive halogen in the marine boundary layer and in the upper troposphere and lower stratosphere. In the marine boundary layer, inorganic bromine $(\mathrm{Br})$ and iodine (I), which are involved in free radical chemistry, originate in part from their organic counterparts and influence tropospheric oxidation capacity via a number of reaction cycles. These include catalytic ozone $\left(\mathrm{O}_{3}\right)$ destruction (Read et al., 2008); modification of $\mathrm{NO}_{\mathrm{x}}$ (Sander et al., 1999; Pszenny et al., 2004) and $\mathrm{HO}_{\mathrm{x}}$ (Stutz et al., 1999; Bloss et al., 2005; Sommariva et al., 2006) cycles with resulting effects on lifetimes of other climatically important trace gases; oxidation of DMS (von Glasow et al., 2004); and oxidation of S(IV) in acidified sea salt aerosol and cloud droplets (Vogt et al., 1996). In the lower stratosphere, $\mathrm{Br}$ dramatically accelerates the chlorine-driven depletion of ozone. On a per-atom basis, $\mathrm{Br}$ is about 60 times more effective than chlorine in depleting ozone (Law and Sturges, 2007). Longer-lived source gases alone cannot account for the total amount of inorganic bromine in the lower stratosphere (Dorf, 2005; Law

Published by Copernicus Publications on behalf of the European Geosciences Union. 
and Sturges, 2007) and it is becoming increasingly apparent that about $20-35 \%$ of the $\mathrm{Br}$ in the lower stratosphere derives from very short-lived halocarbons that are rapidly convected from the marine boundary layer (Kritz et al., 1993; Law and Sturges, 2007). Chlorine (Cl) from very short-lived gases presents fewer pressing issues, as its sources are primarily derived from longer-lived organic compounds, such as CFCs or $\mathrm{CH}_{3} \mathrm{Cl}$ (stratosphere) and sea salt aerosol (troposphere). However, $\mathrm{Cl}$ was not excluded from our discussion.

While atmospheric budgets for longer-lived, anthropogenic halocarbons are reasonably well constrained, quantifying sources and sinks of very short-lived halocarbons is challenging. The combination of short tropospheric lifetimes, seawater removal, and a variety of natural sources leads to substantial variability in mixing ratios and fluxes. Improving understanding of the contribution of these important halogen sources to stratospheric and tropospheric chemistry is in part limited by a lack of common calibration and measurement comparisons among laboratories. This problem is further complicated because measurements of these gases are needed in both liquid and gaseous media. The origin of very short-lived halocarbons is primarily oceanic and their consequences are atmospheric, so their study has involved two research communities, generally working separately. Thus, there is a need to develop calibration and comparison approaches that are well suited for both media, at part-per-trillion levels. The absence of a formal process for ensuring comparability of measurements has precluded or obscured the reliable, unbiased merging of data from disparate sources

Several studies highlight the variability in oceanic concentrations and atmospheric fluxes, with reported values varying by several orders of magnitude (Fig. 1). They also underscore the need for common calibration scales and a mechanism for direct comparison of analytical approaches. Observed variations result, in part, from natural spatial and temporal differences, but it is not always clear how much the discrepancies emanate from analytical or calibration dissimilarities. Without these distinctions, one cannot confidently differentiate between spatial and temporal variability and systematic offsets. Consistency of calibration is particularly important for experiments involving multiple investigators and multiple platforms in which the principal aim is to quantify fluxes of very short-lived source and product gases entering the upper troposphere. Despite an increasing volume of publications and revealing results, calibration issues continue to limit the ability of researchers to take full advantage of growing data sets. Combining data into a global dataset without reference to calibration could diminish the utility of the database as a whole.

Seeking to address this issue, thirty-one scientists from eight nations gathered in February, 2008, at the Novartis Institute in London (Appendix A). The aim was to plan an international effort that would ensure traceability to common calibration scales for oceanic and atmospheric measurements
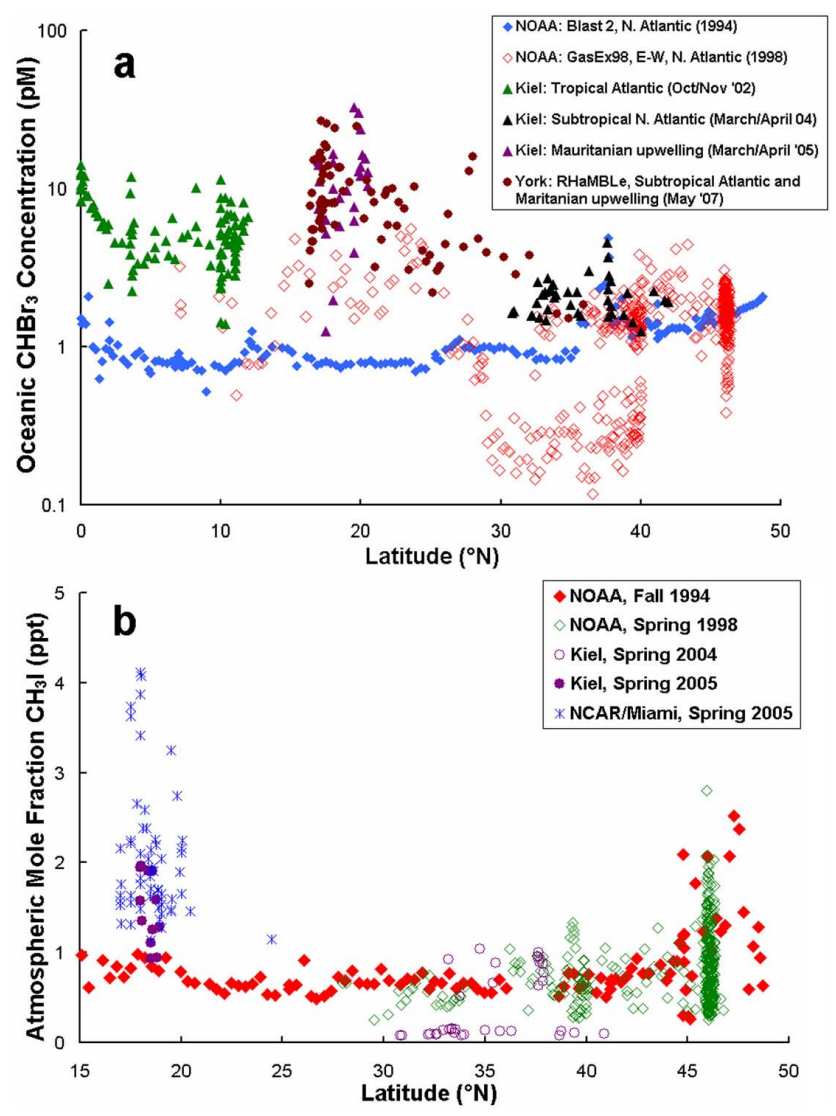

Fig. 1. Spatial and temporal variations in very short-lived trace gas composition are highly variable in both the ocean and the atmosphere. This variability, combined with a diversity of measurement approaches, confounds our ability to discern actual differences from analytical ones. Consequently, the lack of a common calibration scale and on-going comparisons diminishes the value of combined data sets, in spite of the amount of data available. Selected examples include (a) reported oceanic $\mathrm{CHBr}_{3}$ concentrations (pM) in surface waters of the North Atlantic Ocean, which vary by orders of magnitude (note $\log$ scale), and (b) atmospheric mole fractions $\mathrm{CH}_{3} \mathrm{I}$ (ppt) in the marine boundary layer over the North Atlantic Ocean from 1994-2005. Without traceability, different investigators cannot reliably determine that data yielding similar results are in actual agreement, much less have certainty that observed differences are real. Figure 1a presents data from various sources: NOAA data (closed blue diamonds and open red diamonds, Butler et al., 2007); Kiel data (closed green triangles, Quack et al., 2004; closed black triangles, B. Quack unpublished data, Meteor 60/5, 2004; closed purple triangles, Quack et al., 2007); and York data (closed red spots, Carpenter et al., 2009). Figure 1b presents data from NOAA (closed red diamonds and open green diamonds, Butler et al., 2007), Kiel (open and closed purple dots, Richter, 2003) and NCAR/Miami (blue diamonds, Quack et al., 2007).

of very short-lived, volatile halocarbons. Discussions focused on determining the scope of the scientific need, identifying which compounds should be targeted, identifying opportunities for beginning calibration and comparison efforts, 
and prescribing a way forward for improving the comparability of measurements.

\section{Discussion}

Ensuring traceability and confidence in long-term records requires, at a minimum, extensive comparison among research groups. Bi-lateral comparisons have been performed occasionally during field studies, and the results of some of these comparisons have led to increased interest in calibration procedures. However, a broader, on-going comparison is needed. It was recognized that initial efforts should focus on the measurement of substances in air, as gases could be stored for longer periods and are not subject to as many interferences as in a liquid medium. For the most part, investigators from both communities can measure the compounds in air with existing apparatus. Participants agreed that initial comparisons should focus on a few select species thought to be the most important in terms of bromine and iodine $\left(\mathrm{CHBr}_{3}, \mathrm{CH}_{2} \mathrm{Br}_{2}\right.$, and $\left.\mathrm{CH}_{3} \mathrm{I}\right)$. This also takes advantage of the fact that knowledge of stability in gas cylinders (at both low and high pressures) is more mature for these gases. Additional species such as $\mathrm{CH}_{2} \mathrm{BrCl}, \mathrm{CH}_{2} \mathrm{ICl}$, and $\mathrm{CH}_{2} \mathrm{I}_{2}$ could also be measured, but their stability in stored containers remains in question at this time.

A comprehensive effort to ensure comparability of measurements must include (1) a commonly used and wellmaintained reference scale for each gas, (2) a mechanism for participating laboratories to trace measurements to those scales, and (3) routine exchange of flasks of air, whether through round-robins or distribution of samples from batch preparations. It was also suggested that periodic intensive studies involving a large number of investigators would be critical to addressing the comparability of measurements made in both air and water.

Although there are at least three laboratories (NOAA Earth System Research Laboratory Global Monitoring Division, Scripps Institution of Oceanography, and University of Miami) that maintain scales or references for these gases, there is no existing source of funding to initiate the activities needed for this process. Current efforts, then, are subject to ad-hoc comparisons initiated by individual investigators, which is an improvement over not comparing at all, but short of what is needed to support coherent global data. In the end, the community needs to find a home for this coordination effort. The WMO Global Atmosphere Watch program hosts scientific advisory groups for greenhouse gases, ozone, reactive gases, aerosols, and precipitation chemistry. The WMO advisory groups work with the atmospheric community to establish calibration centres, measurement guidelines, and coordinating assistance, so that future participants can ensure the value of their measurements to the global community. Unfortunately, naturally-occurring, very short-lived halocarbons do not fit neatly into any of the current groups.
Efforts to improve calibration and comparison efforts are underway and WMO is being sought as a host for these activities. Interested investigators involved in the measurement of very short-lived halocarbons and other related trace gases should contact one of the authors for information on current comparison activities. Alternatively, visit the Surface Ocean - Lower Atmosphere Study (SOLAS) project integration website for more information (http://tinyurl.com/4xwzpa).

\section{Appendix A}

\section{Scientists attending the Very Short-Lived Halocarbon Intercalibration Workshop, London, UK, 2008}

$\begin{array}{ll}\text { Abrahmsson, Katrina } & \text { Chalmers University of Tech., Göteborg, } \\ & \text { Sweden } \\ \text { Atlas, Elliot } & \text { University of Miami, USA } \\ \text { Bell, Thomas } & \text { University of East Anglia, Norwich, UK } \\ \text { Blake, Don } & \text { University of California, Irvine, USA } \\ \text { Butler, James } & \text { NOAA Earth System Research Laboratory, } \\ & \text { USA } \\ \text { Carpenter, Lucy } & \text { University of York, UK } \\ \text { Hall, Brad } & \text { NOAA Earth System Research Laboratory, } \\ & \text { USA } \\ \text { Harris, Neil } & \text { University of Cambridge, UK } \\ \text { Hughes, Claire } & \text { University of East Anglia, Norwich, UK } \\ \text { Jones, Charlotte } & \text { University of York, UK } \\ \text { Karlsson, Anders } & \text { Chalmers University of Tech., Göteborg, } \\ & \text { Sweden } \\ \text { Laube, Johannes } & \text { Frankfort University, Germany } \\ \text { Maione, Michela } & \text { University of Urbino, Pesaro, Italy } \\ \text { Martino, Manuela } & \text { University of East Anglia, Norwich, UK } \\ \text { Milton, Martin } & \text { National Physical Laboratory, Teddington, } \\ & \text { UK } \\ \text { Moore, Bob } & \text { Dalhousie University, Halifax, Canada } \\ \text { Morin, Pascal } & \text { Station Biologique de Roscoff, France } \\ \text { Nightingale, Phil } & \text { Plymouth Marine Laboratory, UK } \\ \text { O’Doherty, Simon } & \text { University of Bristol, UK } \\ \text { Oram, David } & \text { University of East Anglia, Norwich, } \\ & \text { UK } \\ \text { Quack, Birgit } & \text { IFM-GEOMAR, Keil, Germany } \\ \text { Raimund, Stefan } & \text { Station Biologique de Roscoff, France } \\ \text { Scholer, Heinfried } & \text { Heidelberg, Germany } \\ \text { Schulz-Bull, Detlef } & \text { University of Heidelberg, Germany } \\ \text { Sive, Barkley } & \text { University of New Hampshire, USA } \\ \text { Smythe-Wright, Denise } & \text { National Oceanography Centre, } \\ & \text { Southampton, UK } \\ \text { Von Glasow, Roland } & \text { University of East Anglia, Norwich, UK } \\ \text { Warwick, Nicola } & \text { University of Cambridge, UK } \\ \text { Weiss, Ray } & \text { University of California, San Diego, USA } \\ \text { Williams, Jonathan } & \text { Max Planck Institute for Chemistry, } \\ & \text { Mainz, Germany } \\ \text { Yokouchi, Yoko } & \text { National Institute for Environmental } \\ \text { Studies, Ibaraki, Japan } \\ & \\ & \end{array}$

Acknowledgements. The workshop held at the Novartis Institute, London, in February 2008 would not have been possible without the support of the SOLAS International Project Office (IPO); the Natural Environment Research Council (NERC) through UK-SOLAS Knowledge Transfer funds; and the European Science 
Foundation (ESF) through COST (Cooperation in the field of Scientific and Technical Research) Action 735 funds. We thank Jeff Hare and Georgia Bayliss-Brown (SOLAS IPO) for their significant contribution toward the organization of the workshop. Tom Bell and SOLAS Project Integration are supported by a UK SOLAS Knowledge Transfer grant (NE/E001696/1). We also thank three anonymous reviewers who helped improve this manuscript.

Edited by: A. Hofzumahaus

\section{References}

Bloss, W. J., Lee, J. D., Johnson, G. P., Sommariva, R., Heard, D. E., Saiz-Lopez, A., Plane, J. M. C., McFiggans, G., Coe, H., Flynn, M., Williams, P., Rickard, A. R., and Fleming, Z. L.: Impact of halogen monoxide chemistry upon boundary layer $\mathrm{OH}$ and $\mathrm{HO}_{2}$ concentrations at a coastal site, Geophys. Res. Lett., 32, L06814, doi:10.1029/2004GL022084, 2005.

Butler, J. H., King, D. B., Lobert, J. M., Montzka, S. A., YvonLewis, S. A., Hall, B. D., Warwick, N. J., Mondeel, D. J., Aydin, M., and Elkins, J. W.: Oceanic distributions and emissions of short-lived halocarbons, Global Biogeochem. Cy., 21, GB1023, doi:10.1029/2006GB002732, 2007.

Carpenter, L. J., Jones, C. E., Dunk, R. M., Hornsby, K. E., and Woeltjen, J.: Air-sea fluxes of biogenic bromine from the tropical and North Atlantic Ocean, Atmos. Chem. Phys., 9, 1805-1816, 2009 ,

http://www.atmos-chem-phys.net/9/1805/2009/.

Dorf, M.: Investigation of inorganic stratospheric bromine using balloon-borne DOAS measurements and model simulations, University of Heidelberg, Heidelberg, Germany, available online at: http://tinyurl.com/dy6p89, 2005.

Ko, M. K. W. and Poulet, G. (lead authors): Very short-lived halogen and sulphur substances. Chapter 2 in: Scientific Assessment of Ozone Depletion: 2002. Global Ozone Research and Monitoring Project - Report No. 47, World Meteorological Organization, Geneva, Switzerland, 2003.

Kurylo, M. J. and Rodriguez, J. M. (lead authors): Short-lived ozone-related compounds. Chapter 2 in: Scientific Assessment of Ozone Depletion: 1998. Global Ozone Monitoring Project - Report No. 44, World Meteorological Organization, Geneva, Switzerland, 1999.

Kritz, M. A., Rosner, S. W., Kelly, K. K., Loewenstein, M., and Chan, K. R.: Radon measurements in the lower tropical stratosphere: Evidence for rapid vertical transport and dehydration of tropospheric air, J. Geophys. Res.-Atmos., 98, 8725-8736, 1993.

Law, K. S. and Sturges, W. T. (lead authors): Halogenated very short-lived substances, Chapter 2 in: Scientific Assessment of Ozone Depletion: 2006, Global Ozone Research and Monitoring Project - Report No. 50, World Meteorological Organization, Geneva, Switzerland, 572 pp., 2007.
Olsen, S. C., Hannegan, B. J., Zhu, X., and Prather, M. J.: Evaluating ozone depletion from very short-lived halocarbons, Geophys. Res. Lett., 27(10), 1475-1478, 2000.

Pszenny, A. A. P., Moldanov, J., Keene, W. C., Sander, R., Maben, J. R., Martinez, M., Crutzen, P. J., Perner, D., and Prinn, R. G.: Halogen cycling and aerosol $\mathrm{pH}$ in the Hawaiian marine boundary layer, Atmos. Chem. Phys., 4, 147-168, 2004, http://www.atmos-chem-phys.net/4/147/2004/.

Quack, B., Atlas, E., Petrick, G., Stroud, V., Schauffler, S., and Wallace, D. W. R.: Oceanic bromoform sources for the tropical atmosphere, Geophys. Res. Lett., 31, L23S05, doi:10.1029/2004GL020597, 2004.

Quack, B., Atlas, E., Petrick, G., and Wallace, D. W. R.: Bromoform and dibromomethane above the Mauritanian upwelling: Atmospheric distributions and oceanic emissions, J. Geophys. Res.Atmos., 112, D09312, doi:10.1029/2006JD007614, 2007.

Read, K. A., Mahajan, A. S., Carpenter, L. J., Evans, M. J., Faria, B. V. E., Heard, D. E., Hopkins, J. R., Lee, J. D., Moller, S. J., Lewis, A. C., Mendes, L., McQuaid, J. B., Oetjen, H., SaizLopez, A., Pilling, M. J., and Plane, J. M. C.: Extensive halogenmediated ozone destruction over the tropical Atlantic Ocean, Nature, 453, 1232-1235, 2008.

Richter, U.: Factors influencing methyl iodide production in the ocean and its flux to the atmosphere, Ph.D. thesis, University of Kiel, Kiel, Germany, 2003.

Sander, R., Rudich, Y., von Glasow, R., and Crutzen, P. J.: The role of $\mathrm{BrNO}_{3}$ in marine tropospheric chemistry: A model study, Geophys. Res. Lett., 26, 2857-2860, 1999.

Sommariva, R., Bloss, W. J., Brough, N., Carslaw, N., Flynn, M., Haggerstone, A. L., Heard, D. E., Hopkins, J. R., Lee, J. D., Lewis, A. C., McFiggans, G., Monks, P. S., Penkett, S. A., Pilling, M. J., Plane, J. M. C., Read, K. A., Saiz-Lopez, A., Rickard, A. R., and Williams, P. I.: $\mathrm{OH}$ and $\mathrm{HO}_{2}$ chemistry during NAMBLEX: roles of oxygenates, halogen oxides and heterogeneous uptake, Atmos. Chem. Phys., 6, 1135-1153, 2006, http://www.atmos-chem-phys.net/6/1135/2006/.

Stutz, J., Hebestreit, K., Alicke, B., and Platt, U.: Chemistry of halogen oxides in the troposphere: Comparison of model calculations with recent field data, J. Atmos. Chem., 34, 65-85, 1999.

Vogt, R., Crutzen, P. J., and Sander, R.: A mechanism for halogen release from sea-salt aerosol in the remote marine boundary layer, Nature, 383, 327-330, 1996.

von Glasow, R., von Kuhlmann, R., Lawrence, M. G., Platt, U., and Crutzen, P. J.: Impact of reactive bromine chemistry in the troposphere, Atmos. Chem. Phys., 4, 2481-2497, 2004, http://www.atmos-chem-phys.net/4/2481/2004/. 